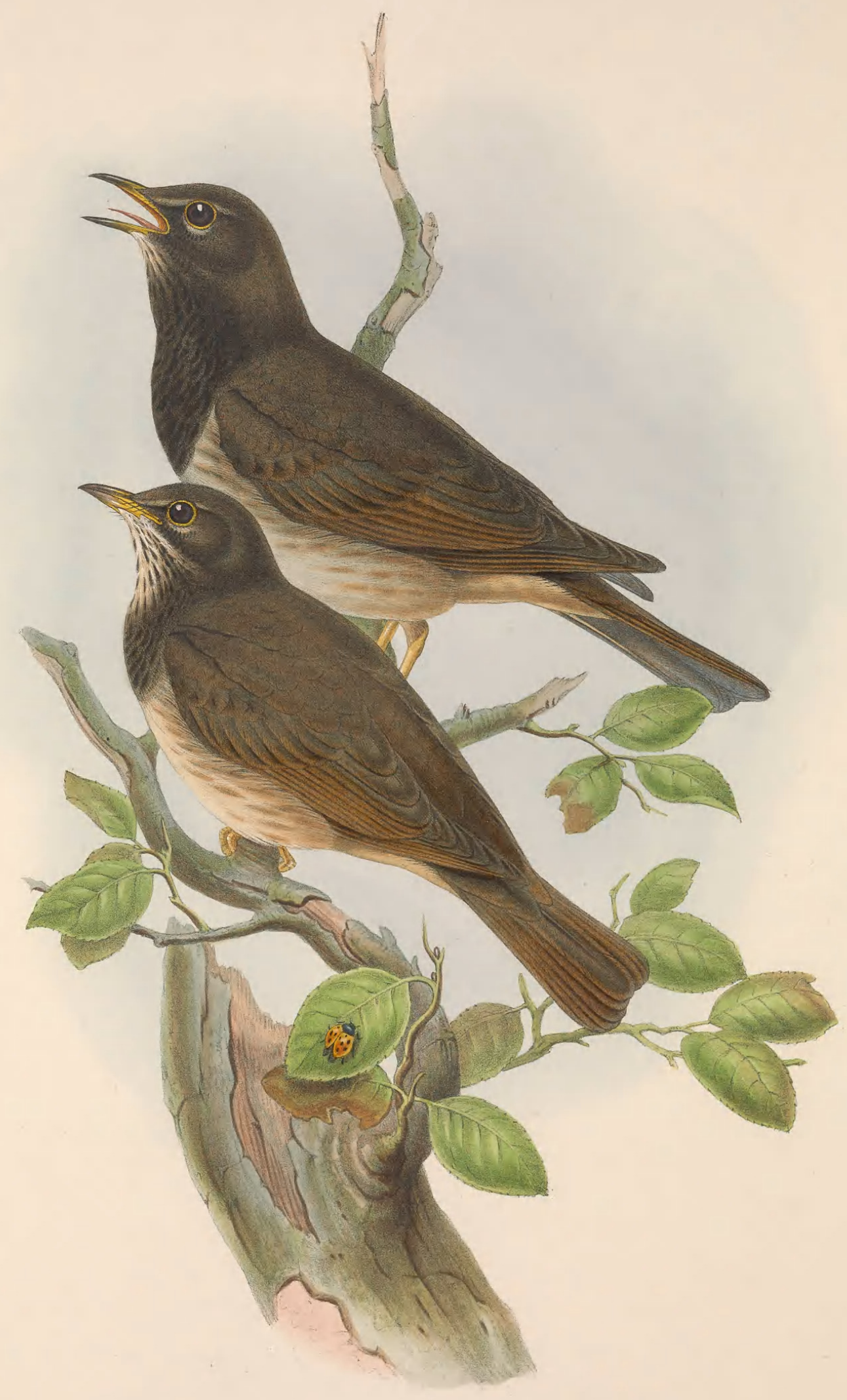




\title{
TURDUS ATROGULARIS, Temm.
}

\author{
Black-throated Thrush.
}

\author{
Turdus atrogularis, Temm. Man. d’Orn., 2nd edit., tom. i. p. 169, and tom. iii. p. 93 . \\ dubius, Bechst. \\ Bechsteinii, Naum. Naturg., neue Ausg., tom. ii. p. 310, tab. 69. fig. 1. \\ atrigularis, Schleg. Rev. Crit. des Ois. d'Eur., p. xli. \\ Merula atrogularis, Bonap. Geog. and Comp. List of Birds of Eur. and N. Amer., p. 17. \\ Cichloides Bechsteini, Kaup. \\ Planesticus atrogularis, Jerd. Birds of India, vol. i. p. 529.
}

A Fine example of this species having been killed in England, another instance is thereby afforded of the fact that many birds whose natural homes are in the northern and eastern portions of Asia wander occasionally into countries further west. Mostly they are solitary individuals that thus shift their quarters; but in some cases the movement is effected by hundreds, as in the well-known instance of the Sand-Grouse (Syrrhaptes paradoxus), flocks of which resorted to Europe in the years 1859-60. In like manner examples of the present species have, now and then, for a long period visited the European countries contiguous to Siberia and Western Asia, but until lately have not been found so far westward as the British Islands. The particulars connected with the solitary example of the bird that has as yet been detected on our shores, and from which one of my figures on the opposite Plate has been taken, will be found in the following notes forwarded to me by T. J. Monk and George Dawson Rowley, Esqs. The former gentleman says, "On Wednesday last (Dec. 23, 1868) a fine example of the Black-throated Thrush (Turdus atrogularis) was shot near Lewes, and is now in my possession. It is, I believe, the first obtained in Great Britain. The specimen, which proved to be a male, is in excellent condition, and has been well preserved by Swaysland, of Brighton. Mr. G. D. Rowley will take it to London and exhibit it at the meeting of the Zoological Society on the 13th of January next, and will leave the bird with you, should you wish to figure it in your "Birds of Great Britain." “I think it a matter of interest," says Mr. Rowley, " that a Thrush belonging to the fauna of Central Asia, and only an accidental visitor to Europe, should be found on the south coast of Great Britain." Mr. Blyth says (in 'The Ibis,' new series, vol. iv. 1868, p. 355) that some examples of T. atrigularis have the tail more or less rufous, as in T.ruficollis, —and adds, "I suspect that T. atrogularis and T. ruficollis are specifically identical. I believe, however, that most authors consider them distinct species, in which you also concur."

As the individual above mentioned was not allowed to live an hour after it was seen, no opportunity was afforded for observing its habits and actions - which is the more to be regretted, inasmuch as but little has been written respecting them by any one : that they vary in some slight degree from those of the other members of the faunily there can be little doubt, since in form and general appearance the bird differs from all the European Thrushes - a circumstance which has led to two or three generic appellations being applied to it, as will be seen in the above list of synonyms. In one respect it is certainly very peculiar, namely in the great variation of plumage to which it is subject-some individuals having speckled and spotted throats and sides, somewhat like true Thrushes, while in others the throat is jet black. I have not seen any with reddish tail-feathers or any rufous colouring on the throat sufficiently apparent to warrant my believing the $T$. atrogularis and the $T$. ruficollis of Pallas to be one and the same species, as they are believed to be by some ornithologists; and as I find that Mr. Jerdon keeps them separate, I shall continue to do the same; for if they really be identical, then many other so-called species, such as $T$. Naumanni and $T$. fuscatus must be united, and the list of birds greatly diminished in number.

"This Thrush," says Mr. Jerdon, "is found throughout the Himalayas, inhabiting the higher ranges in the interior in summer, but descending to the lower ranges in winter; and it is even occasionally found in the plains of Lower Bengal. Mr. Blyth records its having been shot at Barrackpore, near Calcutta. I found it not uncommon near Darjeeling in winter. It keeps to the more open woods, at a level of from three to eight thousand feet, and is occasionally seen on roads and pathways. It feeds on insects and berries."

Dr. Bree remarks that "this bird is an inhabitant of Siberia, whence it occasionally migrates into Russia, Hungary, Silesia, and Austria. Its occurrence in Europe, however, is only accidental; and little or nothing is known of its habits. It ranges south as far as Nepaul."

I am especially indebted to Arthur Grote, Esq., for some fine examples of this bird which he has 
kindly presented to me; of these a fine male and a female (shot at Lahore), from the collection of C. H. T. Marshall, Esq., present such a marked difference, particularly in the colouring of the throat, that I have considered it desirable to describe them, and also another specimen differing from both, from the collection of $\mathrm{Mr}$. Jerdon.

The male has all the upper surface of the body and the tail clear brown; the outer margins of the secondaries slightly tinged with light reddish-brown; axillaries rich orange-brown; throat and chest black, each feather slightly margined with light grey; centre of the abdomen dull white with dashes of brown on the flanks and under tail-coverts; bill black at the tip, at the base white, but here it has evidently been yellow.

The female is similar to the male; the throat as well as the centre of the abdomen dull white with strong dashes of white down the sides of the neck, and a conspicuous pectoral band of similar blotches across the chest; the flanks marked in like manner with brown; over the eye a buffy white supercilium.

Mr. Jerdon's specimen has the centre of the throat and the abdomen dull white, with distinct spots or guttated markings across the chest; on the sides of the body these markings assume the form of striæ.

This specimen, besides having a shorter tail, is considerably smaller than the others, so much so as almost to lead to the inference of its being a distinct bird.

The figures are of the size of life. 


\section{$2 \mathrm{BHL}$ Biodiversity Heritage Library}

Gould, John. 1873. "Black-throated Thrush, Turdus atrogularis [PI. 36]." The birds of Great Britain 2, -. https://doi.org/10.5962/p.323850.

View This Item Online: https://www.biodiversitylibrary.org/item/221554

DOI: https://doi.org/10.5962/p.323850

Permalink: https://www.biodiversitylibrary.org/partpdf/323850

\section{Holding Institution}

Smithsonian Libraries

\section{Sponsored by}

Biodiversity Heritage Library

\section{Copyright \& Reuse}

Copyright Status: Public domain. The BHL considers that this work is no longer under copyright protection.

This document was created from content at the Biodiversity Heritage Library, the world's largest open access digital library for biodiversity literature and archives. Visit BHL at https://www.biodiversitylibrary.org. 